\title{
Reassignment of the Genus Ectothiorhodospira Pelsh 1936 to a New Family, Ectothiorhodospiraceae fam. nov., and Emended Description of the Chromatiaceae Bavendamm 1924
}

\author{
JOHANNES F. IMHOFF \\ Institut für Mikrobiologie, D-5300 Bonn, Federal Republic of Germany
}

\begin{abstract}
I propose that the genus Ectothiorhodospira be placed in a new family, the Ectothiorhodospiraceae, as the only genus. The reasons for this proposal are discussed briefly, and a description of the new family and an emended description of the Chromatiaceae are given.
\end{abstract}

Two groups of phototrophic purple bacteria were distinguished by Molisch (13); these are the Thiorhodaceae, comprising all purple bacteria that are able to form globules of elemental sulfur inside their cells, and the Athiorhodaceae, comprising bacteria which lack this ability. These groups have been maintained and were treated as families of the Pseudomonadales (suborder Rhodobacteriinae) in Bergey's Manual of Determinative Bacteriology, 7th ed. (1). In Bergey's Manual, 8th ed., these two groups appeared as the Rhodospirillaceae Pfennig and Trüper 1971 and the Chromatiaceae Bavendamm 1924, respectively (16). In this latter edition the ability of the species to use sulfide as the sole photosynthetic electron donor and to form elemental sulfur as an intermediate oxidation product, inside or outside cells, was used as one of the major criteria to distinguish between the two families. Thus, because of its ability to form and oxidize elemental sulfur, the new (see below) genus Ectothiorhodospira Pelsh 1936 could be included in the family Chromatiaceae; within this family, only Ectothiorhodospira species deposit elemental sulfur outside their cells.

The ability of various Rhodospirillaceae species to oxidize sulfide is now well established $(2-4,12,13 a)$. Most of the species with this ability form either elemental sulfur or sulfate as the only oxidation product, but Rhodopseudomonas sp. strain 51 (2) and Rhodopseudomonas adriatica (13a), similar to Ectothiorhodospira species, deposit elemental sulfur during sulfide oxidation to sulfate intermediately outside their cells. Therefore, the ability to oxidize sulfide and elemental sulfur is no longer a suitable property to distinguish between the Rhodospirillaceae and the Chromatiaceae. A redefinition of these families is required, and it seems useful to return to the definition of the Thiorhodaceae of Molisch (13). This consequently leads to separation of Ectothiorhodospira from the Chromatiaceae.

The first description of an Ectothiorhodospira species, Ectothiorhodospira mobile (sic), was published by Pelsh (14), who later (15) distinguished these bacteria as members of the "Ectothiorhodaceae" from the "Endothiorhodaceae" (Chromatiaceae Bavendamm 1924, nomen conservandum proposed by Pfennig and Trüper in 1971) and the "Ectothiochlorobacteriaceae" (Chlorobiaceae Copeland 1956). The organism of Pelsh was lost, and knowledge about this work did not reach the literature of the western world until Trüper (17) reisolated and redescribed Ectothiorhodospira mobilis. Since then five more species of this genus have been described; these are Ectothiorhodospira shaposhnikovii Cherni et al. 1969, Ectothiorhodospira halophila Raymond and Sistrom 1969, Ectothiorhodospira halochloris Imhoff and Trüper 1979 (8), Ectothiorhodospira abdelmalekii Imhoff and Trüper 1982 (9), and Ectothiorhodospira vacuolata Imhoff et al. 1982 (7). (E. halochloris, E. abdelmalekii, and $E$. vacuolata were effectively published by Imhoff et al. [7-9], and the publication of these names was later validated in the International Journal of Systematic Bacteriology $(10,11)$; the years given above refer to the dates of validation.) The Ectothiorhodospira species form a distinct group among the phototrophic purple bacteria, and the arguments below support treatment of this group as a taxon support treatment of this group as a taxon separated from both the Rhodospirillaceae and the Chromatiaceae.

(i) Ectothiorhodospira species are unique among the phototrophic purple bacteria in their requirement for saline to extremely saline and alkaline growth conditions, and therefore are enriched and isolated under conditions not suitable for other phototrophic purple bacteria (18). (ii) Analyses of $16 \mathrm{~S}$ ribosomal ribonucleic acids show that Ectothiorhodospira stands clearly apart from the Rhodospirillaceae and is also distinctively different from the Chromatiaceae species that deposit elemental sulfur globules inside their cells (16a). (iii) The lipid compositions of all Ectothiorhodospira species are significantly different from those of Rhodospirillaceae and Chromatiaceae species. Ectothiorhodospira species lack glycolipids, which are characteristic of the Chromatiaceae, and they also lack ornithine lipids, which are characteristic of the Rhodospirillaceae (6). (iv) The major quinones found in the extremely halophilic species are menaquinones and ubiquinones with eight isoprenoid units in their side chains, like the quinones found in Chromatium and related genera. The species with lower salt requirements have only seven isoprenoid units in the side chains of their major ubiquinones and menaquinones. No other phototrophic purple bacteria are known to contain this combination of $\mathrm{MK}-7$ and Q-7 (5). (v) The amino acid sequences of the cytochrome $c_{551}$ molecules of the extremely halophilic Ectothiorhodospira species, E. halophila, E. halochloris, and E. abdelmalekii, are not similar to the amino acid sequence of any cytochrome $c$ analyzed from the Rhodospirillaceae or the species retained within the Chromatiaceae (T. E. Meyer, Abstr. IVth Int. Symp. Photosynthetic Procaryotes, A46, 1982; R. P. Ambler, personal communication). (vi) Those Rhodopseudomonas species that oxidize sulfide to sulfate via intermediate deposition of elemental sulfur are significantly different from Ectothiorhodospira species, both physiologically and on the basis of molecular structure $(2,13 \mathrm{a})$. (vii) In removing Ectothiorhodospira from the Chromatiaceae, this family becomes clearly defined; all of its members deposit elemental sulfur during sulfide oxidation inside their cells.

Therefore, I propose that Ectothiorhodospira be placed in the new family Ectothiorhodospiraceae as its only genus, 
with Ectothiorhodospira as the type genus and Ectothiorhodospira mobilis Pelsh 1936 as the type species of this genus.

Description of Ectothiorhodospiraceae fam. nov. Ectothiorhodospiraceae (Ec.to.thi.o.rho.do.spi.ra'ce.ae. M.L.fem.n. Ectothiorhodospira type genus of the family; -aceae ending to denote a family; M.L. fem.pl.n. Ectothiorhodospiraceae Ectothiorhodospira family) cells are spiral, vibrioid, or rod shaped with intracytoplasmic membranes that are continuous with the cytoplasmic membrane and present as lamellar stacks. The photosynthetic pigments are bacteriochlorophyll $a$ or $b$ and carotenoids. Cells are motile by means of polar flagella and do or do not contain gas vacuoles.

Growth occurs in the light under anaerobic conditions or at low $\mathrm{pO}_{2}$ values, and some species also grow at low $\mathrm{pO}_{2}$ values in the dark. Photoautotrophic growth may or may not be possible. A number of organic carbon sources are photoassimilated or used as photosynthetic electron donors. Sulfide is oxidized to elemental sulfur, which is deposited outside the cells and may be further oxidized to sulfate. Sulfate may or may not be used as a sole sulfur source under photoheterotrophic growth conditions. No growth factors are required, but vitamin $B_{12}$ enhances the growth of some strains.

The deoxyribonucleic acid base composition ranges from $50.5 \mathrm{~mol} \%$ guanine plus cytosine ( $E$. halochloris) to 69.9 mol\% guanine plus cytosine ( $E$. halophila).

Most characteristic is the dependence on saline and alkaline growth conditions. The presently known species grow optimally between $\mathrm{pH} 7.5$ and 9.1 and at a total salt concentration of 3 to $30 \%$. Accordingly, members of the Ectothiorhodospiraceae are found in nature in marine to extremely saline environments containing sulfide and having alkaline $\mathrm{pH}$ values and can be selectively enriched under such conditions. They may also occasionally be found in soil, but not in nonalkaline freshwater habitats.

Emended description of the Chromatiaceae Bavendamm 1924. The description is essentially the same as that given by Pfennig and Trüper (16), except as noted below. Individual cells are spherical, ovoid, rod shaped, or spiral shaped, rarely vibrioid. During sulfide oxidation globules of elemental sulfur accumulate intermediately inside the cells in all species; such globules never accumulate outside the cells. This property clearly distinguishes the Chromatiaceae from the other families of phototrophic purple and green bacteria, as previously recognized as a characteristic feature of the "Thiorhodaceae" by Molisch (13).

I thank H. G. Trüper and N. Pfennig for discussions about the matters related to this paper.

My experimental results cited were obtained during work supported by a grant from the Deutsche Forschungsgemeinschaft.

\section{LITERATURE CITED}

1. Breed, R. S., R. G. E. Murray, and R. E. Smith. 1957. Bergey's manual of determinative bacteriology, 7 th ed. The Williams \& Wilkins Co., Baltimore.

2. Hansen, T. A., A. B. J. Sepers, and H. van Gemerden. 1975. A new purple bacterium that oxidizes sulfide to extracellular sulfur and sulfate. Plant Soil 43:17-27.

3. Hansen, T. A., and H. van Gemerden. 1972. Sulfide utilization by purple nonsulfur bacteria. Arch. Mikrobiol. 86:49-56.

4. Hansen, T. A., and H. Veldkamp. 1973. Rhodopseudomonas sulfidophila, nov. spec., a new species of the purple nonsulfur bacteria. Arch. Mikrobiol. 92:45-58.

5. Imhoff, J. F. 1982. Taxonomic and phylogenetic implications of lipid and quinone compositions in phototrophic microorganisms, p. 541-544. In J. F. G. M. Wintermans and P. J. C. Kuiper (ed.), Biochemistry and metabolism of plant lipids. Elsevier Biomedical Press, Amsterdam.

6. Imhoff, J. F., D. J. Kushner, S. C. Kushwaha, and M. Kates. 1982. Polar lipids in phototrophic bacteria of the Rhodospirillaceae and Chromatiaceae families. J. Bacteriol. 150:1192-1201.

7. Imhoff, J. F., B. J. Tindall, W. D. Grant, and H. G. Trüper. 1981. Ectothiorhodospira vacuolata sp. nov., a new phototrophic bacterium from soda lakes. Arch. Microbiol. 130:238-242.

8. Imhoff, J. F., and H. G. Trüper. 1977. Ectothiorhodospira halochloris sp. nov., a new extremely halophilic phototrophic bacterium containing bacteriochlorophyll b. Arch. Microbiol. 114:115-121.

9. Imhoff, J. F., and H. G. Trüper. 1981. Ectothiorhodospira abdelmalekii sp. nov., a new halophilic and alkaliphilic phototrophic bacterium. Zentralbl. Bakteriol. Parasitenkd. Infektionskr. Hyg. Abt. 1 Orig. Reihe C 2:228-234.

10. International Journal of Systematic Bacteriology. 1979. Validation of the publication of new names and new combinations previously effectively published outside the IJSB. List no. 2. Int. J. Syst. Bacteriol. 29:79-80.

11. International Journal of Systematic Bacteriology. 1982. Validation of the publication of new names and new combinations previously effectively published outside the IJSB. List no. 8. Int. J. Syst. Bacteriol. 32:266-268.

12. Keppen, O. I., and V. M. Gorlenko. 1975. A new species of purple budding bacteria containing bacteriochlorophyll b. Microbiology (USSR) 44:224-229.

13. Molisch, H. 1907. Die Purpurbakterien nach neuen Untersuchungen. G. Fischer, Jena.

13a.Neutzling, O., J. F. Imhoff, and H. G. Trüper. 1984 Rhodopseudomonas adriatica spec. nov., a new species of the Rhodospirillaceae, dependent on reduced sulfur compounds. Arch. Microbiol. 137:256-261.

14. Pelsh, A. D. 1936. Hydrobiology of Karabugaz Bay of the Caspian Sea. Tr. Solyanoi Lab. Vses. Inst. Metallurgii NIS NKT. Izdatelstvo Akad. Nauk SSSR (Moscow-Leningrad) 5:49-126.

15. Pelsh, A. D. 1937. Photosynthetic sulfur bacteria of the eastern reservoir of Lake Sakskoe. Mikrobiologiya 6:1090-1100.

16. Pfennig, N., and H. G. Trüper. 1974. The phototrophic bacteria, p. 24-64. In R. E. Buchanan and N. E. Gibbons (ed.), Bergey's manual of determinative bacteriology, 8 th ed. The Williams \& Wilkins, Co., Baltimore.

16a.Stackebrandt, E., V. J. Fowler, W. Schubert, and J. F. Imhoff. 1984. Towards a phylogeny of phototrophic purple sulfur bacteria-the genus Ectothiorhodospira. Arch. Microbiol. 137:366370 .

17. Trüper, H. G. 1968. Ectothiorhodospira mobilis Pelsh, a photosynthetic sulfur bacterium depositing sulfur outside the cells. J. Bacteriol. 95:1910-1920.

18. Trüper, H. G., and J. F. Imhoff. 1981. The genus Ectothiorhodospira, p. 274-278. In M. P. Starr, H. Stolp, H. G. Trüper, A. Balows, and H. G. Schlegel (ed.), The Procaryotes. A handbook on habitats, isolation, and identification of bacteria. Springer-Verlag, Heidelberg. 